\title{
Productive Performance of White Leghorn Hens Based on the Type of Housing During Rearing: Floor Versus Cage
}

Technical Note

EAuthor(s)

\author{
Itza-Ortiz MF' \\ Peraza-Mercado G \\ Castillo-Castillo $Y^{\prime}$ \\ Rodriguez-Alarcon CA \\ Vital-Garcia $\mathrm{C}^{\prime}$ \\ Jaramillo-Lopez E \\ Carrera-Chavez JM
}

Universidad Autónoma de Ciudad Juárez, Depto. Ciencias Veterinarias. Av. Benjamin Franklin \#4651, Circuito Pronaf, 32315, Cd. Juárez, Chihuahua

\section{Mail Address}

Corresponding author e-mail address Dr. Mateo Fabian Itza Ortiz

Avenida Plutarco Elias Calles \#1210

Col. Foviste Chamizal, CP. 32310

Cd. Juárez, Chihuahua, México.

Tel: $\quad(+52)(656) 6881825$, ext. 1445

Email: mateo.itza@uacj.mx

\section{EKeywords}

Feed intake, productive performance, mortality, egg production, rearing method.

\section{ABSTRACT}

Poultry farmers in the southeastern of Mexico consider that the productivity of the hens that comes from rearing on floor has a higher productive performance than reared hens in cages, mainly due to higher percentage of egg laying and lower mortality. The aim of this study was to evaluate the productive performance of the laying hen in relation to the type of rearing. A total of 79680 pullets Bovans White of 17 weeks of age were housed in cages with five pullets cage ${ }^{-1}$ (405 $\mathrm{cm}^{2}$ pullet $\left.{ }^{-1}\right)$. They were divided in two treatments according to their type of rearing (floor vs cage) with four replicates. The study period was from week 20 to week 40 of age. The variables evaluated were daily (\%) and cumulative mortality (\%), egg production (\%), egg weight (g), feed intake ( $g$ pullet $\left.\mathrm{d}^{-1}\right)$, cumulative feed intake (g pullet-1), daily and cumulative egg mass, number of eggs per hen housed, egg loss (\%) and productivity index. The variables were analyzed using a randomized block design. It was observed that daily and cumulative mortality, feed intake and egg loss was higher $(p<0.05)$, while the number of eggs per hen housed and productivity index $(p<0.05)$ was lower for hens in cages. We conclude that it is possible to associate detriments in the productive performance of laying hens based on the type of housing during its growth phase.

\section{INTRODUCTION}

Feed intake $\left(g\right.$ hen $\left.\mathrm{d}^{-1}\right)$ and egg weight $(\mathrm{g})$ are relevantparameters in the poultry industry economy. However, other parameters such as daily and cumulative mortality (\%), egg production (\%), cumulative conversion $\left(\mathrm{kg} \mathrm{kg}^{-1}\right)$, daily egg mass, and the number of eggs per hen housed are important when evaluating the productive performance of a flock that is measured as productivity index.

The type of housing that the replaced pullets receive during rearing, influence directly the productive performance during growth, resulting in a higher body weight for the housed on the floor compared to the caged ones (Itza et al., 2011). It is an important fact that the pullet's body weight reaches sexual maturity at 16 weeks of age, due to the effect it has over the beginning of the egg laying until the production peak and during all the productive cycle (Lamazares, 2006). In tropical conditions and the southeastern of Mexico, poultry farmers believe that hens productivity housed and rearing at farms on the floor have a higher productive performance than the reared in cages. The reason is that hens in cages have a lower body weight at 16 weeks of age compared to the standard (1170 g; Bovans White Guide, 2012), not maintaining the onset of the egg laying curve (production), nor reaching the production peak. Also its daily and cumulative mortality are higher than those reared on the floor. There is no information to evaluate how 
Itza-Ortiz MF, Peraza-Mercado G, Castillo-Castillo Y, Rodriguez-Alarcon CA, Vital-Garcia C, Jaramillo-Lopez E, Carrera-Chavez JM
Productive Performance of White Leghorn Hens Based on the Type of Housing During Rearing: Floor Versus Cage the type of housing (floor versus cage) during rearing affects the future commercial laying hen; nowadays researchers are currently seeking to improve growth performance and streamline productivity of the flock. Hence, the objective of this study was to evaluate the productive performance of commercial laying hens about the type of housing during their rearing on the floor versus cage.

\section{MATERIALS AND METHODS}

The study was conducted in a commercial hen farm of the genetic line Bovans White, located in the state of Yucatan, Mexico, 20 $56^{\prime}$ 53.57" N and 89 ${ }^{\circ} 56^{\prime} 06.14^{\prime \prime}$ $\mathrm{W}$ at a height of $7 \mathrm{~m}$ about sea-level rise. The climate is type Aw0, the driest of the hot climates, sub-humid according to the Köppen classification modified by García (1973), with an annual temperature between 21.0 and $33.8^{\circ} \mathrm{C}$ (Itzá et al., 2006).

\section{Characteristics of the growth phase}

Pullets reared on the floor were illuminated with fluorescent lamps of $15 \mathrm{~W}$, reared in housings with dimensions of $10 \times 75 \mathrm{~m}$, where 12000 pullets by housing were kept to have an initial density of 16 pullets $\mathrm{m}^{-2}\left(625 \mathrm{~cm}^{2}\right.$ pullet-1). The housings were equipped with automatic feeders Chore-Time (ChoreTime Systems, Jacksonville, FLA, USA), with two lines of 103 dishes each one, 70 hopper type feeders (Agricultural Systems JAT, Zapopan, Jalisco, Mexico) for manual feed, distributed longitudinally to the center of the housing for 43 pullets trough ${ }^{-1}, 90$ bell type drinker (Agricultural Systems JAT, Zapopan, Jalisco, Mexico) for 133 pullets drinker ${ }^{-1}, 12$ gas brooders model Dyc-50 (Dycomet S. A. de C. V., Santa Catarina, Mexico DF, Mexico).The pullets reared in cages were illuminated with fluorescent lamps of $15 \mathrm{~W}$. The housings had dimensions of $10 \times 100 \mathrm{~m}$, with cages of $61 \times 71 \times 40 \mathrm{~cm}$, grouped in the shape of a pyramid with three rows per side and three pyramids by the housing. For a total of 2610 cages housing $^{-1}, 26100$ pullets housing ${ }^{-1}$ were reared, with a density of 10 pullets cage $^{-1}\left(433 \mathrm{~cm}^{2}\right.$ pullet $^{-1}$ ). Each cage had a nipple type drinker (ChoreTime Systems, Jacksonville, FLA, USA) and a trough type feeder (Agricultural Systems JAT, Zapopan, Jalisco, Mexico), which ran across the length of each level, making useful $71 \mathrm{~cm}$ of trough cage ${ }^{-1}(7.1 \mathrm{~cm}$ trough pullet $\left.^{-1}\right)$, which received food semi-automatically. Also, the housings were equipped with four turbo type heaters model L.B. White Series V 115 (L.B. White, Carlsbad, CA, USA), distributed two per side, at a distance of $30 \mathrm{~m}$ between them. In both types of housing, the illumination calendar corresponded to a light descending program, vaccination schedules, formulation of the diets and the nutrients profile were organized based on the recommended production guide (Bovans White Guide, 2012).

At week 17 the pullets were transferred to the egglaying farm in cages where data were recorded. The research started during week 20 and ended at week 40 of age.

\section{Characteristics of the production phase}

The commercial egg laying farm had eight housings each with dimensions of $10 \times 100 \mathrm{~m}$; equipped with type JIPSA (Merida, Yucatan, Mexico) cages of $45 \times 45 \times 40 \mathrm{~cm}$ grouped in the shape of a pyramid with two rows per side and two pyramids per housing for a total of 1992 cages housing ${ }^{-1}$. A total of 9960 pullets of 17 weeks of age were reared housing ${ }^{-1}$, being five pulletscage-1 $\left(405 \mathrm{~cm}^{2}\right.$ pullet-1 $)$. The housings had fibercement and metal sheet roof, cement floor, and were surrounded with nylon mesh. Each cage had a nipple type drinker (Jacksonville, FLA, USA) and a plastic trough type feeder (Zapopan, Jalisco, Mexico) that ran across the length of each level, being $45 \mathrm{~cm}$ of feeder per cage $\left(4.5 \mathrm{~cm}_{\text {trough pullet }}{ }^{-1}\right)$, and filled manually. The housing was lit with 40 fluorescent $13 \mathrm{~W}$ lamps. All the pullets received food and water ad libitum, the formulation of the diets and the nutrients profile were based on the recommendations of the Production Guide (Bovans White Guide, 2012), and an increasing light calendarwas used (16L:8D) that started at 20 weeks of age.

This research did not require the approval of a bioethics committee to accomplish this investigation because the pullets under study did not receive a different treatment from those found in commercial egg production in cages as currently performed on egg laying business farms in Mexico. Therefore Mexican laws, humanitarian care or Norma Oficial Mexican a regarding the handling off arm animals (NOM-051ZOO-1995, NOM-033-SAG-ZOO-2014) were not violated.

The response variables were daily mortality (\%), cumulative mortality (\%), egg production (\%), egg weight (g), food consumption (g pullet $\mathrm{d}^{-1}$ ), cumulative food consumption ( $\mathrm{g}$ pullet $^{-1}$ ), daily egg mass ( $\mathrm{g}$ ), accumulated egg mass ( $g$ ), number of eggs per hen housed, productivity index, and egg loss (total quantity of broken and cracked eggs expressed as a percentage). 
Itza-Ortiz MF, Peraza-Mercado G,

Castillo-Castillo Y, Rodriguez-Alarcon CA,

Vital-Garcia C, Jaramillo-Lopez E,

Carrera-Chavez JM
Productive Performance of White Leghorn Hens Based on the Type of Housing During Rearing: Floor Versus Cage

\section{Statistical analysis}

$$
Y_{i j}=\mu+\alpha_{i+} \beta_{i j+} \varepsilon_{i j}
$$

A total of 79680 pullets were housed and distributed in two treatments according to the type of housing (floor or cage) during their rearing, with four replicates per treatment. The data were analyzed using the PROC GLMSAS procedure (SAS Institute, 2004) under a randomized block design which explained the total variation, and is represented as:

$Y_{i j}=$ individual observation; $\mu=$ experimental average; $\alpha_{i}=$ effect of the type of hen housing during the rearing (floor or cage); $\beta_{\mathrm{ij}}=$ effect of the egg laying housing; $\varepsilon_{\mathrm{ij}}=$ random error.

When the model was significant at $p<0.05$, means were separated using the Student-Newman-Keuls multiple range test (Mendenhall, 1994). Additionally, the Pearson correlation between the number of eggs per hen housed and cumulative mortality applying SAS (SASInstitute,2004) was used.

\section{RESULTS AND DISCUSSION}

The results obtained are presented in Table 1, differences $\left(p \leq 0.05 ; r^{2}=14.16\right)$ can be appreciated in the daily mortality rate being higher for hens that were reared in cage compared to the reared on the floor. The previous resulted in a greater cumulative mortality $\left(p \leq 0.05 ; r^{2}=92.26\right)$ of the caged ones in comparison to the reared on the floor. The farm mortality is a factor that might be associated with infectious or non infectious problems. Non-infectious problems are those that primarily involve internal causes related to the production and application of biological, nutritional and health issues. The external environmental factors such as extreme temperature that causes heat stress (Itza et al., 2006) might also affect egg production. The housing design, size, and orientation of the cage (Garner et al., 2012.), race, body weight and age at sexual maturity also influence hens performance (Llamazares et al., 2006; Itza et al., 2011). In the present study, all hens were from the same strain, were subjected to the same diet, environmental characteristics and management; however they had a different rearing system during their growth phase, which could have influenced the mortality. Hens reared in cages tend to present nervous temper (Holzebosch, 2006; Shinmura et al., 2006).

Another factor to consider is the maximum temperature $\left({ }^{\circ} \mathrm{C}\right)$ which had a significant effect $(p \leq 0.05$; $\left.r^{2}=92.26\right)$ on the cumulative mortality, related to the months of May and June with a higher temperature (monthly average of $37.40^{\circ} \mathrm{C}$ ) in the study area. The months above match the ones reported by Itza et al. (2006) regarding mortality. However, the main factor is the relative humidity (\%) that can also affect feed intake, egg weight and the egg laying percentage (Sykes, 1979; Zumbado, 2003).

Feed intake was higher $\left(p \leq 0.05 ; r^{2}=52.24\right)$ for hens reared in caged; it must be considered that they were housed at the egg laying farm having a lower body weight $(1027 \pm 6.78 \mathrm{~g})$ then the reared on the floor $(1083 \pm 9.81 \mathrm{~g})$. Also, there is no information on the increased feed intake as compensation for a low bodyweight to maintain egg production, compared to other species that tend to increase feed intake after a period of starvation (Summers \& Leeson, 1983; Koelkebcck et al., 1993; Coffey et al., 2001).

TABLE 1 - Productive performance of Leghorn hen according to the type of housing, floor compared to cages during their rearing.

\begin{tabular}{|c|c|c|c|}
\hline \multirow[b]{2}{*}{ Productive parameter } & \multicolumn{3}{|c|}{ Treatment (mean \pm S.D.) } \\
\hline & Floor & Cage & Probability \\
\hline Daily mortality (\%) & $0.218^{b} \pm 0.125$ & $0.329^{\mathrm{a}} \pm 0.322$ & $* \star \star$ \\
\hline Cumulative mortality (\%) & $2.390^{b} \pm 1.497$ & $5.584^{\mathrm{a}} \pm 2.071$ & $* \star *$ \\
\hline Egg laying (\%) & $81.297^{a} \pm 23.994$ & $80.681^{\mathrm{a}} \pm 23.946$ & NS \\
\hline Egg average weight (g) & $57.801^{\mathrm{a}} \pm 4.039$ & $57.702^{\mathrm{a}} \pm 5.073$ & NS \\
\hline Feed intake $\left(\mathrm{g} \mathrm{hen}^{-1}\right)$ & $89.859^{b} \pm 5.368$ & $91.981^{\mathrm{a}} \pm 5.631$ & ** \\
\hline Cumulative conversion $\left(\mathrm{kg} \mathrm{kg}^{-1}\right)$ & $3.577^{a} \pm 6.283$ & $5.141^{\mathrm{a}} \pm 11.410$ & NS \\
\hline Daily egg mass & $48.168^{a} \pm 15.001$ & $47.623^{a} \pm 15.238$ & NS \\
\hline Cumulative egg mass & $46.969^{a} \pm 14.540$ & $45.511^{\mathrm{a}} \pm 14.285$ & NS \\
\hline \# egg hen housed ${ }^{-1}$ & $58.190^{a} \pm 39.204$ & $55.904^{b} \pm 37.892$ & ** \\
\hline Productivity index & $159.965^{b} \pm 82.593$ & $147.493^{\mathrm{a}} \pm 78.284$ & $* \star *$ \\
\hline Egg loss (\%) & $1.329^{b} \pm 0.500$ & $1.631^{\mathrm{a}} \pm 0.411$ & ** \\
\hline
\end{tabular}

ab Different letters between columns are significant $(p \leq 0.05)$

* Significant difference $p \leq 0.05 ; * *$ Significant difference $p \leq 0.01 ; * * *$ Significant difference $p \leq 0.001 ; N S=$ Non significant

AMean \pm S.D. 
Itza-Ortiz MF, Peraza-Mercado G, Castillo-Castillo Y, Rodriguez-Alarcon CA, Carrera-Chavez JM Vital-Garcia C, Jaramillo-Lopez E,

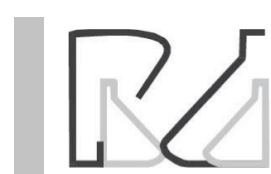

The egg laying percentage, egg weight, daily and cumulative egg mass did not present differences $\left(p \leq 0.05 ; r^{2}=85.81\right)$ among the hens according to the type of housing they received during the growth phase. Cumulative feed conversion neither was affected $\left(p \leq 0.05 ; r^{2}=34.09\right)$. Egg laying percentage, egg weight, egg mass, and feed conversion are parameters that are related to the feed energy, protein, amino acids, essential fatty acid, and environmental, and management (Summers \& Leeson, 1983; Itza et al., 2006; Lamazares et al., 2006; Itza et al., 2011). The genetic strain also plays a major role in hens performance (Shalev \& Pasternak, 1993), and performance results might not directly be influenced by the type of housing during the growth phase. Saki et al. (2012) reported no differences $(p>0.05)$ in egg production on densities of $2000,1000,667$ and $500 \mathrm{~cm}^{2}$ hen $^{-1}$. The results of the present study with a density of $405 \mathrm{~cm}^{2}$ hen $^{-1}$ are similar to those reported by the authors (Saki et al., 2012) with $500 \mathrm{~cm}^{2}$ hen $^{-1}$, supporting the possibility of having five hens per cage without compromising egg production.

The number of eggs per hen housed was higher for the ones that were housedon the floor during the growth phase. Also, there was a correlation of 68.14 between this variable and the cumulative mortality (Figure 1). Differences were found $\left(p \leq 0.05 ; r^{2}=27.66\right)$ in the egg loss and egg production rate $\left(p \leq 0.05 ; r^{2}\right.$ $=36.26$ ) between hens according to the type of housing during the growth phase. The previously mentioned parameters directly affected the production rate being higher in hens reared on the floor compared to those in cages.

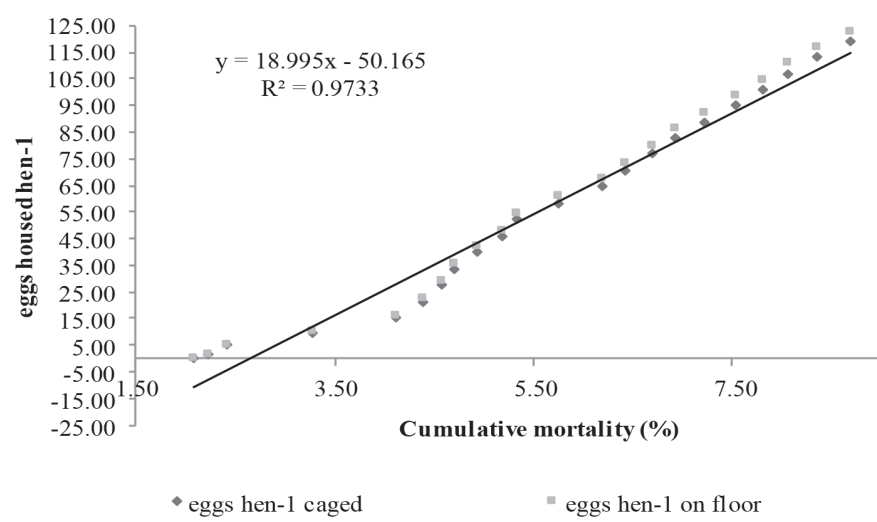

Figure 1 - Linear correlation of eggs per hen housed and cumulative mortality (\%) of Leghorn hen according to the type of housing during their rearing.

The smaller amount of eggs per housedhen in the caged hens might be due to the fact that the layerspresenteda low increase in the production curve (Figure 2) from week 22 to week 28, a period in which the maximum peak of production is reached according to the Technical Manual of the Lineage (Bovans White
Productive Performance of White Leghorn Hens Based on the Type of Housing During Rearing: Floor Versus Cage

Guide, 2012). The flock that does not reach the peak of production has a negative impact on the total egg accumulated per housing hen. However, the persistence in the egg production of the caged hens was similar to the one on the floor after week 29, and both are found to be in the standard or over the standard after week 37 (Figure 2).

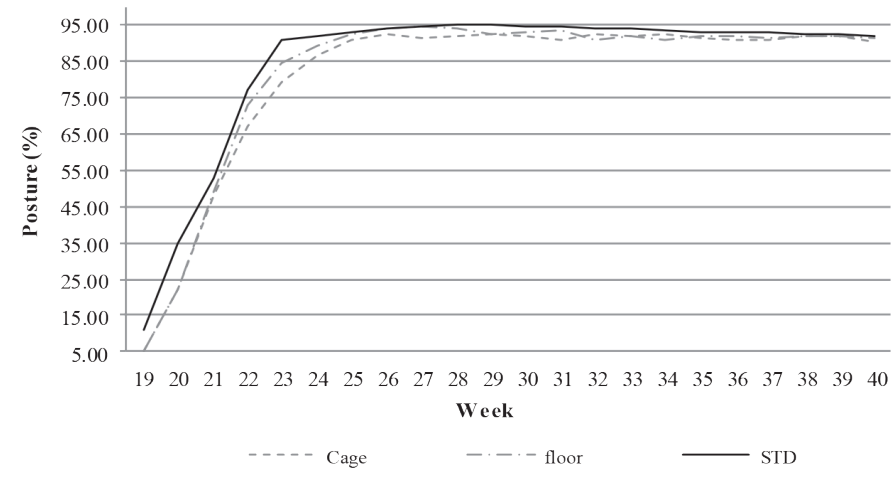

Figure 2 - Egg production curve of Leghorn hen based on the type of housing during their rearing.

The caged hens presented a restless behavior (Holzebosch, 2006; Itza et al., 2011) and this stress can cause a decrease in the absorption of minerals such as calcium from feed source by triggering a mobilization of calcium stored in the long eggs (keel and tarsi) to ensure the calcification of the egg (Estrada-Osmaida et al., 2008). Consequently, this increases the need of phosphorus and the egg's shell fragility, producing an increase of broken or cracked eggs, as observed in eggs from caged hens during the growth phase. Although there were no problems of cage fatigue during the trial period, a problem associated with the deficiency of calcium in the diet; the productive results in quantitative terms such as the number of eggs per hen housed and the production curve were adversely affected, impacting the productivity rate negatively.

\section{CONCLUSIONS}

It was possible to associate the differences of the productive performance of hens in relation to the growth phase, with parameters like daily and cumulative mortality (\%), daily feed intake $\left(g\right.$ hen $\left.^{-1}\right)$, the number of eggs accumulated by hen housed, egg loss and consequently on the production rate. Also, the hens housed in cages have a lower egg production peak; however, they maintain the egg production curve after week 29 of age as those reared on the floor. It is suggested that further research needs tobe conducted to clarify if the nervous temper of the hens reared in cages is related to the differences in the number of eggs per hen housed and egg loss. 
Itza-Ortiz MF, Peraza-Mercado G,

Castillo-Castillo Y, Rodriguez-Alarcon CA,

Vital-Garcia C, Jaramillo-Lopez E,

Carrera-Chavez JM

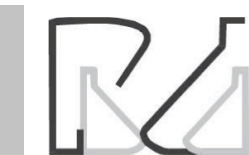

\section{REFERENCES}

Bovans White Management Guide [cited 2016 Abr 6]. Washington: Centurión Poultry; 2012. Available from: http://www.hendrix-poultry.nl/.

Coffey KP, Coblentz WK, Humphry JB. Review: basic principles and economics of transportation shrink in beef cattle. The Professional Animal Scientist 2001;17:247-255.

Estrada-Osmaida C, Larrent-Marroquin N, Angelita-Cos TD, Yusell-Bárzaga GR. La calcárea phosphórica en el mejoramiento de la calidad de la cáscara del huevo en gallinas ponedoras. REDVET 2008;9(3):1-5.

García E. Modificación al sistema de clasificación climática de Köppen: para adaptarlo a las condiciones de la República Mexicana. México: UNAM; 1973. $246 \mathrm{p}$

Garner JP, Kiess AS, Mench JA, Newberry RC, Hester PY. The effect of cage and house design on egg production and egg weight of White Leghorn hens: An epidemiological study. Poultry Science 2012;91:1522-1535.

Holzebosch J. Wide range of housing options for layers. World Poultry 2006;22(6):20-22.

Itza MF, García L, Castro F. Consumo de alimento, causa y porcentaje de mortalidad en granjas de postura comercial bajo condiciones climáticas de Yucatán, México. Veterinaria México 2006;37(3):379-390.

Itza OMF, Ortiz OJ, Janacua VH, Olguín AHA, Quintero EJA, Rodríguez ACA, et al. Características de crecimiento de pollitas de postura en relación al tipo de alojamiento. Pesquisa Agropecuaria Brasileira 2011;46(7):768771.

Koelkebcck KW, Parson CM, Leeper RW. Effect of early feed with drawal on subsequent laying hen performance. Poultry Science 1993;72:22292235.

Lamazares MC. Estudio morfométrico del inicio- reemplazo de ponedoras [cited 2015 Feb 23].REDVET 2006;7(10). Available from: http://www. veterinaria.org/revistas/redvet/n101006/100614.pdf.
Productive Performance of White Leghorn Hens Based on the Type of Housing During Rearing: Floor Versus Cage

Mendenhall W. Introduction to probability and statistics. In: Mendenhal W, Beaver RJ, editors. Introduction to linear model and the design and analysis of experiments. Belmont: Duxbury; 1994. p.244-251.

NOM - Norma Oficial Mexicana - 051-ZOO-1995 [cited 2015 Feb 23] Available from: http://www.senasica.gob.mx/?id=787.

NOM - Norma Oficial Mexicana - 033-SAG_ZOO-2014 [cited 2015 Set 28]. Available from: http://www.senasica.gob.mx/?id=787.

Saki AA, Zamani IP, Rahmati M, Mahmoudi H. The effect of cage density on laying hen performance, egg quality, and excreta minerals. Journal Applied Poultry Research 2012;21:467-475.

SAS Institute. SAS ${ }^{\circledR} / \mathrm{STAT}$ software: changes and enhancements through release 8.1. Cary: SAS Institute; 2004. 956 p.

Shalev BA, Pasternak $\mathrm{H}$. Increment of egg weight with hen egg size in various commercial avian species. British Poultry Science 1993;34:915924

Shinmura T, Eguchi Y, Uetake K, Tanaka T. Behavioral changes in laying hens after introduction to batterycages, furnished cages and an aviary. Animal Science Journal 2006;77:242-249.

Summers JD, Leeson S. Factors influencing early egg size. Poultry Science $1983 ; 62: 1155-1159$.

Sykes $\mathrm{AH}$. Environmental temperature and energy balance in the laying hen. In: Boorman KN, Freeman BM, editors. Food intake regulation in poultry. Edinburgh: British Poultry Science;1979. p.50-207.

Zumbano ME. Nutrición y manejo de ponedoras comerciales bajo estrés calórico. Tecnología Avipecuaria 2003;182:48-52. 
